\title{
Research of the Lost Circulation Curing
}

\author{
Tanyana IVANOVA ${ }^{1 *}$, Aleksandr KORSHUNOV ${ }^{2}$, Vladimir KORETSKIY ${ }^{3}$ and Nikola \\ ABO ISSA 4
}

\begin{abstract}
Authors' affiliations and addresses:
${ }^{1}$ Federal State Budgetary Institution of Science

"Udmurt Federal Research Center of the Ural Branch of the Russian Academy of Sciences ", Institute of Mechanics, 426000, T. Baramzinoy str., 34, Izhevsk, Russia

Tchaikovsky Branch "Perm National Research Polytechnic Institute", 617764, Lenin st., 73,

Tchaikovsky, Russia

e-mail: tatnic2013@yandex.ru

${ }^{2}$ Federal State Budgetary Institution of Science "Udmurt Federal Research Center of the Ural Branch of the Russian Academy of Sciences ", Institute of Mechanics, 426000, T. Baramzinoy str., 34, Izhevsk, Russia

e-mail: maguser_kai@mail.ru

${ }^{3}$ Kalashnikov Izhevsk State Technical University, Izhevsk, Udmurt Republic, Russia e-mail: vpk1973@yandex.ru
\end{abstract}

${ }^{4}$ Damascus University, Faculty of Mechanical and Electrical Engineering, P.O.Box 86 Damascus, Syria

e-mail: nicolanu@scsnet.org

\section{*Correspondence:}

Tanyana Ivanova, Federal State Budgetary Institution of Science "Udmurt Federal Research Center of the Ural Branch of the Russian

Academy of Sciences ", Institute of Mechanics, 426000, T. Baramzinoy str., 34, Izhevsk, Russia e-mail: tatnic2013@yandex.ru

How to cite this article:

Ivanova, T., Korshunov, A., Koretskiy, V. and Abo Issa, N. (2021). Research of the Lost

Circulation Curing. Acta Montanistica Slovaca, Volume 26 (3), 582-592

DOI:

https://doi.org/10.46544/AMS.v26i3.15

\begin{abstract}
Accident-free construction of controlled directional and horizontal wells, as well as the use of an economically profitable and effective method of lost circulation curing, is an urgent problem. In order to opt for the optimal method for lost circulation curing, it is necessary to investigate the causes of losses and methods of studying the absorbing formation, analyze the experience of lost circulation control in the regions, and take up an economically profitable and effective method of lost circulation curing. The work identifies the factors impacting the occurrence of the drilling mud losses. Geophysical research methods are considered to study thief formations. The peculiarities of the considered methods and their economic analysis are given. The identified Selection Method for the measures to prevent and control fluid loss is based on quantitative criteria allowing for the geological structure and hydrodynamic characteristics of formations. The lost circulation curing based on placing cement plugs, the QUICK-STONETM technology, the lost circulation curing based on insulating compound chromium acetate are considered. The economic analysis of the considered methods is given. It has been found that the use of an insulating compound based on chromium acetate is 3.2 times more economical than QUICKSTONETM technology, as well as 1.4 times more than placing the cement plug.
\end{abstract}

\section{Keywords}

lost circulation, formation, drilling mud, geophysical method, cement plug. 


\section{Introduction}

The drilling mud and other fluids losses are one of the main challenges for and gas industry. The annual time spent on their liquidation is enormous. However, these expenses are significantly higher due to the absorption of the cement slurry, the design height of the cement slurry is not ensured, which makes repair work indispensable; during well development (bringing the well on line and after total overhaul), the permeability of productive strata decreases, etc. (Basarygin et al., 2000; Ivanova and Żabińska, 2021). Therefore, one of the ways to shorten the well construction cycle is to improve the methods and means of drilling mud and other fluids loss control in wells.

Drilling mud loss in wells is determined by permeability, porosity, reservoir strength, reservoir pressure, the volume of injected drilling mud and its trait.

When the pressure in the well-bore exceeds the pressure in the formation entered during drilling, the mud from the well, overcoming local hydraulic resistances, penetrates into the pores, channels and fractures of the rocks. A decrease in pressure in the well compared to the reservoir pressure leads to the movement of fluid from the reservoir to the well, i.e., to water and hydrocarbon manifestation. Therefore, one and the same formation can be either loss formation or inflow indication formation (Basaryginet al., 2001; Bulatov et al., 1999).

The occurrence of lost circulation also depends on the drilling method and technology. Mechanical impact (shock, vibration) of the drilling tool on the borehole walls or large excessive pressures can cause the drilling mud loss into previously isolated or not manifested during the drilling-in horizons.

Depending on the thickness and strength of a dense section of rock or cement stone, the value and the loads cycling, destruction can occur at various points: when running or pulling a drilling tool, restoring circulation, drilling, running or cementing a production string, etc. (Fremin et al., 2013).

Other technical and technological reasons contributing to the occurrence of lost circulation are all factors that cause an increase in annulus pressure while flushing of the wells goes on (Akatov et al., 2019).

The phenomenon of absorption is associated with the penetration of permeable and/or incompetent formations during well drilling and is the movement of drilling mud or cement slurry from the well-bore into the formation under the excessive (compared to the formation) hydrostatic (hydrodynamic) pressure that occurs in the well during its drilling (API, 2010).

The factors affecting the drilling mud loss and aspects of work are divided into two groups (Dodok et al., 2017):

1. Geological factors - the type of thief formation, its thickness and depth, insufficient resistance of rocks to hydraulic fracturing, the value of reservoir pressure and characteristics of the reservoir fluid.

2. Technological factors - the quantity and quality of the drilling fluid supplied to the well, the method of drilling, the speed of tripping operations, etc.

Loss begins provided that the penetrated formations have a sufficiently high flow capacity and the pressure difference between the well and the thief zone is above a certain value, called critical.

In case of insufficient strength of rocks, hydraulic fracturing occurs.

Geophysical research methods are considered to study thief formations. Development survey methods include measurements with an electric level gauge, resistivity meter, calliper, as well as micro-logging, electrical logging, radioactive and acoustic logging, deep photography and deep (down-hole) television. Radioactive and acoustic $\operatorname{logs}$ are secondary methods to clarify the boundaries of loss formations. Based on the results of production logging changes in the characteristics of absorbing strata over the area are studied. Radioactive logging diagrams are used to dissect the section, correlate reservoirs, and track changes in lithology and porosity of rocks of the lost circulation horizon. Acoustic logs enable cavernous and fractured rock differences by a sharp decrease in velocity and an increase in the consumption of elastic vibration energy to be localized.

A summary loss scheme is constructed for each area to present the research results visually. Each thief formation is tagged on the gamma logging (GL) and neutron gamma logging (NGL) diagrams recorded in the same well. Then, having made the correlation, the same layers are determined on the typical section of the given area and symbols are put against them in a separate column (Elbakian et al., 2018). At the same time, the type of formation according to the classification, the static level of the liquid in the well according to the measurement data and in terms of pure water, as well as any other information reflecting the characteristics of the thief formation is indicated.

The boundaries of the loss zone, determined with a flow gauge, define the most permeable part of it, which is characterized by large cracks and large communicating caverns (Gaurina-Medimurec et al., 2021; Arjmand et al., 2017). This is generally consistent with the results of comparing the values of the zones of loss, determined with flow meter and geophysical studies.

In most cases, the intervals of the losses on the NGL and GL diagrams are distinguished by decreases in the intensity of secondary gamma radiation and apparent resistivity (Pástor et al., 2020). At the same time, it is necessary to pay attention to the study of cuttings, the analysis results of which are sometimes an indispensable material for the thief formations to be outlined. 
Methods for studying loss formations are the following:

Tracking the decrease in the level (pressure) of the fluid in the well consists in the fact that the well is repleted with fluid to the wellhead, then the addition of fluid is stopped, and the time of the level drop is measured every 5 or $10 \mathrm{~m}$. Measurements continue until the balance is reached in the well, i.e., until the fluid level reaches a static position. The decrease in the level in the well over time is measured with a level gauge or can be recorded with a depth gauge as a pressure-time curve.

Tracking the level rise in drill pipes after an "instant" decrease is achieved by running drill pipes with a diaphragm plug into the borehole and having been destroyed, the fluid from the annular space moves into the drill pipes. As a result, the fluid in the pipes and the annulus is quickly equalized, and the overall fluid level in the well decreases by a value corresponding to the volume of fluid displaced by closed-ended drill pipes (non-stationary flow). The pressure build-up due to the inflow of fluid from the lost circulation horizon is recorded by monitoring the rise in the level in the drill pipes with a level gauge or recording the pressure curve with a down-hole manometer. This research method has significant errors.

The method of tracking the rise of the level in drill pipes after its instant decrease with a sealed wellhead is similar to the previous one with the difference that to prevent fluid overflow; the wellhead is sealed with a preventer or a packer device. Since the rise in the fluid level in the pipes can only be traced up to the mouth, the initial section of the indicator line is obtained by extrapolation. This method suffers from the disadvantages of the previous method.

The most widespread in the study of thief formations are the levels (pressure) in the well observation method and the method of steady-state injection, and the pressure transient test. It is recommended to use the research method with the flow in transition regime if the pressure recovery time exceeds 30 minutes. In this case, the error in determining the specific-injectivity index according to the formulae of the steady-state does not exceed the accuracy of the device (7-10\%). At lower values of the pressure build-up time, the well survey methods should be used under steady-state conditions, or appropriate correction factors should be introduced (Pástor et al., 2020).

\section{Material and Methods}

\section{Experience in lost-circulation control in the regions of the Russian Federation Bashkortostan}

The mining and geological factors of this region are complicated by high-thickness formations, during the drilling of which there are losses of drilling fluid both medium and catastrophic intensity. In addition, often during well drilling, there are inter-layers in the upper intervals that pour out formation water with the hydrogen sulfide.

During the construction of well No. 926G of the Spasskoye field, LLC Bashneft-Drilling, at a depth of $1150 \mathrm{~m}$, the drilling mud loss with an intensity of more than 30 cubic meters per hour and the development of formation water with hydrogen sulfide with a density of 1.06 gram per cubic centimetre (Upper Carboniferous 522-769 m) began, which led to incompatible drilling conditions (Bauer and Toth, 2017; Lawrwnce, 2009; Kuric et al., 2019; Sentyakov et al., 2020). The standard methods for well construction, like viscoelastic compositions, gel cement, etc., came to nothing or had a short-term effect. Mud loss was 543 cubic meters. The total volume of packing clay/gel cement/rubber filler/sawdust was 337 cubic meters. The time spent on the elimination of the complication was 41 days.

To eliminate the complication, 5 cubic meters of QUICK-STONETM composition with a density of 1560 kilogram per cubic meter was injected. As a result of the employment of technology, the loss rate decreased from a total of 1-2 cubic meters per hour.

It took only 6 hours to install the system and the WOC-waiting on cement. The reduction in WOC-waiting on cement in comparison with the classical approach of a cement plug implementation is 21 hours.

\section{Perm Region}

On drilling well No. 314 of the Trifonovskoye field, three losses were recorded.

The first loss occurred on the 3rd day of the well construction at a depth of $50 \mathrm{~m}$ while surface casing drilling went on. For liquidation losses drilling, running and cementing of $426 \mathrm{~mm}$ of the surface casing were carried out by top out cementing.

The second lost circulation (complete lost circulation) occurred on the $4^{\text {th }}$ day of drilling at a bottom-hole of $73 \mathrm{~m}$. A cement plug was installed (OK BT - $47 \mathrm{~m}$, PCT - 6 tons). The plug was not met; the loss was total. In further drilling, from a depth of $77 \mathrm{~m}$, partial circulation appeared, from a depth of $90 \mathrm{~m}$ - the total loss was again.) Drilling was carried out without a circulation outlet (with stops for a collection of service water) (Figiel and Klackova, 2020). Launched $324 \mathrm{~mm}$ of surface conductor at a depth of 111 meters and cemented by top out cementing. (The depth of lowering $324 \mathrm{~mm}$ of the surface platform was changed from 70 to 110 meters based on the experience of drilling previous wells.) 
The third lost circulation occurred on the 10th day of drilling the well at a depth of 321 meters. Based on the experience of previous wells, prophylactic measures were taken at a depth of 280 meters. A cement bridge was installed in the interval of 249-282 meters before running and fastening a $245 \mathrm{~mm}$ technical column (PCT - 6 tons) to ensure the lifting height of the cement slurry during the cementing and to ensure full squeezing. The most effective (both in terms of quality and time-consuming) method of eliminating lost circulation turned out to be cementing of the columns by the counter-fillings with the installation of a "sleeve" above the loss interval, the least effective - the installation of plugs based on foam cement (in cases of using this method, the loss was not eliminated).

\section{Yamalo-Nenets Autonomous Okrug}

In the field, this insulating composition proved to be effective: at the Urengoyskoye field in the YamaloNenets Autonomous Okrug, at well No. 8835, while drilling at a depth of $2847.6 \mathrm{~m}$, there was a complete loss of circulation. For lost circulation curing to be gained, a clogging-insulating compound based on chromium acetate in a volume of 4 cubic meters was used. During the squeezing and exit of the insulating compound into the open borehole, a circulation output was noted after 1.5 cubic meters had been pumped (the total volume of the pack was 4 cubic meters). Squeezing was continued according to the work plan, i.e., completion of squeezing, another 2.5 cubic meters, occurred when the circulation output was $85-95 \%$ of the volume pumped into the well. Further, the tool was lifted above the interval of setting the insulating composition, followed by squeezing the composition into the thief formation with a stepwise increase in the flow rate of the drilling fluid (Repko et al., 2020). Then the well shut-in time and tool running were done. The bottom-hole zone was flushed, full circulation was not observed, and there was no absorption. Drilling continued in a routine mode.

\section{Characteristics of the considered methods and their economic analysis}

The drilling mud and other fluids losses are one of the main challenges for and gas industry. The annual time spent on their liquidation is enormous (Vasko et al., 2020; Malakova et al., 2019). However, these expenses are significantly higher due to the absorption of the cement slurry, the design height of the cement slurry is not ensured, which makes repair work indispensable; during well development (bringing the well on line and after total overhaul), the permeability of productive stratas decreases, etc. Therefore, one of the ways to shorten the well construction cycle is to improve the methods and means of drilling mud and other fluids loss control in wells.

Methodology for selecting measures to prevent and control fluid loss is based on quantitative criteria allowing for the geological structure and fluid dynamic performance of formations.

\section{Description of the considered methods}

\section{Lost circulation curing by installing cement bridges}

One of the lost circulation control methods is placing cement plugs followed by drilling. The placing of plugs makes it possible to obtain a stable water-gas-oil-tight cement sleeve of a certain strength, strengthen the unstable cavernous part of the well-bore and cure losses.

For the cement plugs to be placed in order to overlap the absorbing intervals, various grouting mixtures are used based on binding materials, polymers, and clay. In most cases, they are prepared on the surface and then transported along the drill string or borehole to the lost circulation zone. In order for the grouting mixture to come to a given interval, its plastic strength, thickening time and setting time should be easily adjusted in relation to specific geological and technical conditions. To prevent the thickening of the grouting mixture when moving to the absorbing interval, at least 10-15 minutes must pass before the start of its setting after the pushing into the formation has been completed. It is necessary that the grouting mixture is resistant to dilution with drilling fluid or formation water and rapidly builds up its structural and mechanical properties after being pushed into the loss formation. The cement must have a compressive strength of at least 0.5-1 MPa after 8-16 hours of hardening and not be destroyed under the effect of aggressive formation waters, temperature and pressure. Production data indicate that plugs to be placed are often leaky and have low strength due to partial or complete erosion of the grouting slurry during placing and setting time. In this regard, certain requirements are imposed on the performance of insulating works and the properties of grouting mixtures.

The made-up grouting mixture must be pumped as it moves from the surface through pipes along the well-bore into the absorption zone, provides an accelerated set of the strength of the cement and reliable blockage of the channels of the loss zone; be able to regulate the structural and mechanical properties and waiting on cement.

Conclusion:

1. Placing a cement plug entails its drilling out, which significantly increases the time for addressing a catastrophic loss.

2. The need to change the assembly of drilling string bottom proves to be essential.

3. There is no possibility of application of the method for a productive formation.

4. Additional processing of the mud comes up, which entails additional costs. 


\section{Curing of losses with QUICK-STONETM technology}

The QUICK-STONE ${ }^{\mathrm{TM}}$ curing method is based on an organo-mineral compound that comprises fine powders with a grain size of up to 7 microns, with a wide range of changes in system density from 1.25 to 2.15 grams per cubic centimetre. The system in its initial state has a water viscosity, is characterized by a controllably fast development of strength, and the composition for its formation is able to completely dissolve in hydrochloric acid, in contrast to standard cement slurries, which are not pumped through the drill bit due to the lack of the above characteristics. This composition can be pumped through the assembly of the drilling string bottom. The recommended injection volume of the composition is $5-10$ cubic meters.

\section{Application.}

The method proves to be efficient while drilling, to address the challenge of damage to a productive formation, to eliminate catastrophic losses, isolate water and gas zones, temporarily kill wells, place a plug for sidetracking, as an alternative to a packer, to consolidate weakly cemented rocks.

Technology.

When QUICK-STONETM hardens, an exothermic reaction occurs (a lot of heat is generated). This may be due to the increased temperature in the formation, which reduces the time to concrete strength development. Other factors such as hydrostatic pressure do not affect the time to concrete strength development. This composition within minutes passes from a liquid to a solid-state, which blocks the channels for gas, water or oil to move along. If necessary, the compressive strength of this compound can be increased to 10,000 psi (69 MPa). At the same time, despite its high strength, this composition is easily drilled out. The composition comprises magnesium oxide, magnesium sulfate heptahydrate, water, sodium hexametaphosphate, aminotris (methylenephosphonic acid).

Damage to the productive formation during drilling and work-over operations may result in significant loss of hydrocarbons or costly remedial work, such as hydraulic fracturing and acid formation treatment. There are many documented evidence of formation damage associated with cement, drilling fluids, etc. In other words, any drilling fluid damages the formation to one degree or another. If the rate of sedimentation of the filtrate is equal to the rate of erosion in the dynamic state, then the invasion of fluids into the formation occurs. The QUICK-STONE TM composition solves this problem. After setting, the composition forms an impermeable layer that does not allow the formation of sediment of the drilling mud filtrate. When selecting the composition, the required setting time and compressive strength can be adjusted by extra inhibitors. Also, the composition is completely soluble in a $15 \%$ hydrochloric acid solution, which reduces to zero contamination of formation, unlike conventional cement.

\section{Conclusion:}

1. The composition allows to significantly reduce the time of catastrophically lost circulation curing with no cement plugs.

2. The change in the assembly of drilling string bottom proves to be not necessary

3. The complete solubility of the composition in hydrochloric acid eliminates contamination of the layers, unlike conventional cement.

\section{Lost circulation curing with Chromium Acetate Sealant}

Chromium acetate is used as a crosslinker for water-polymer systems to enhance oil recovery, levelling the profile log of injection wells and repair and insulation works. It is compatible with most of the gel-forming compounds based on poly-acrylamides, polysaccharides used for work. Chromium acetate enables strong elastic gels to be formed. By varying the concentration, the rate and dynamics of cross-linking can be controlled. Chromium acetate insulating compound is a water-based composition that includes fillers of different fractions, bridging agents, as well as biodegradable polymers with the addition of chromium acetate.

Application.

It is used in the drilling to eliminate catastrophic losses in any interval of the well-bore also in the productive formation.

Technology.

The make-up of the insulating composition is carried out in one of the tanks of the mud mixing system, does not require any additional equipment. Only a Cementing Truck-320 is used for uploading. This composition is easily pumped through the circulation sub included in the assembly of drilling string bottom with measure while drilling, i.e., it does not require changing the assembly of drilling string bottom and time on additional tool lifting. This composition is pumped into the lost circulation zone with drilling fluid with the Cementing Truck-320. After flushing, it should be carried out with a stepwise increase in the flow rate of flushing fluid at the mud pump to ensure that the insulating composition is squeezed into the absorption zone. The final reaction (cross-linking of the solid phase in solution) occurs within 4 to 6 hours. Provided that the bottom hole temperature is not less than 
60 degrees, the reaction time is 4 hours. When using the composition, the setting time can be controlled by adding the required concentration of chromium acetate.

The recommended injection volume of the composition is 5-10 cubic meters. The composition includes the following components: water, caustic soda, heteropolysaccharide, finely ground marble, phlogopite mica fillers, organic bridging additive, bentonite powder.
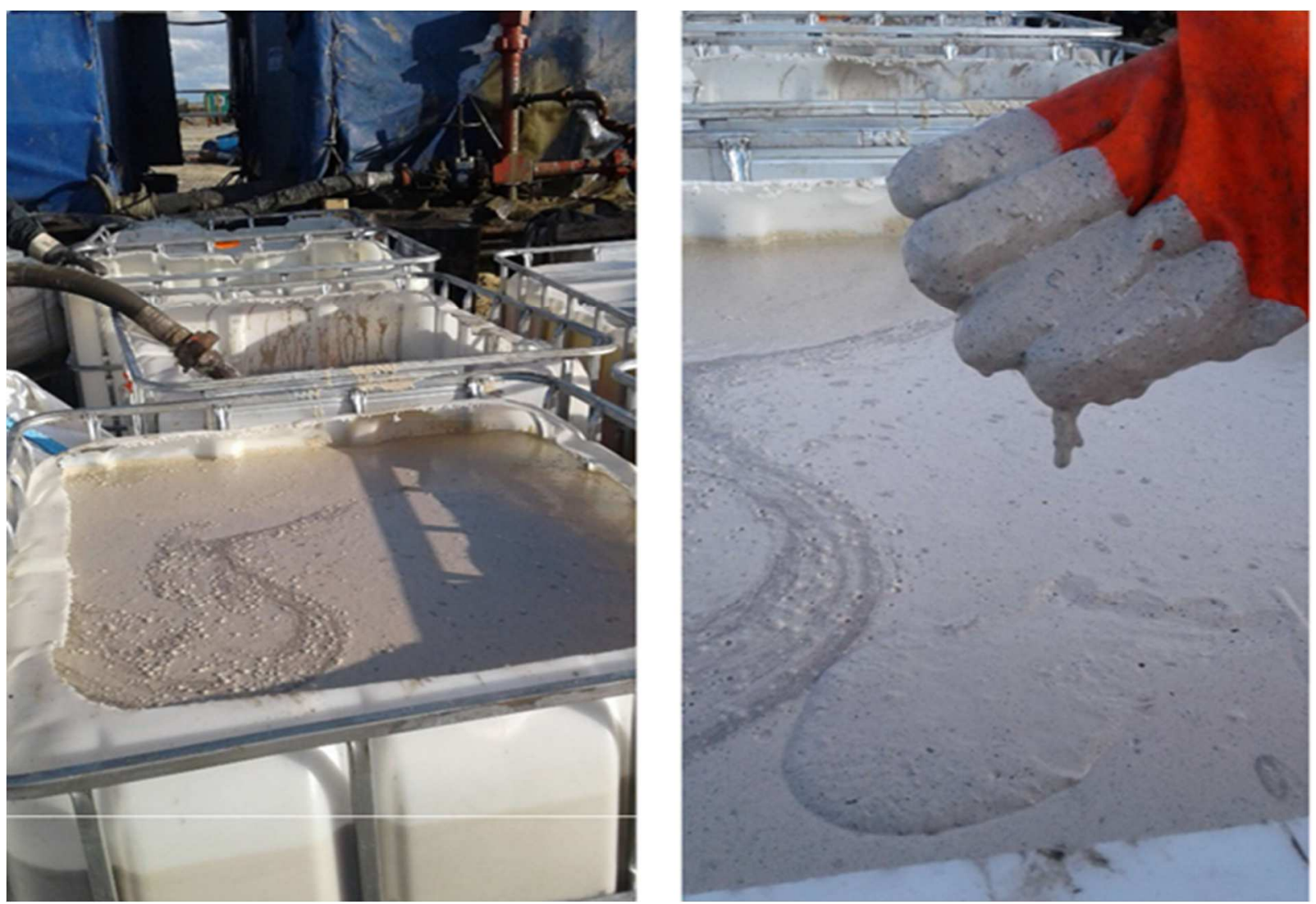

Fig. 1. Base of the insulating compound before adding chromium acetate

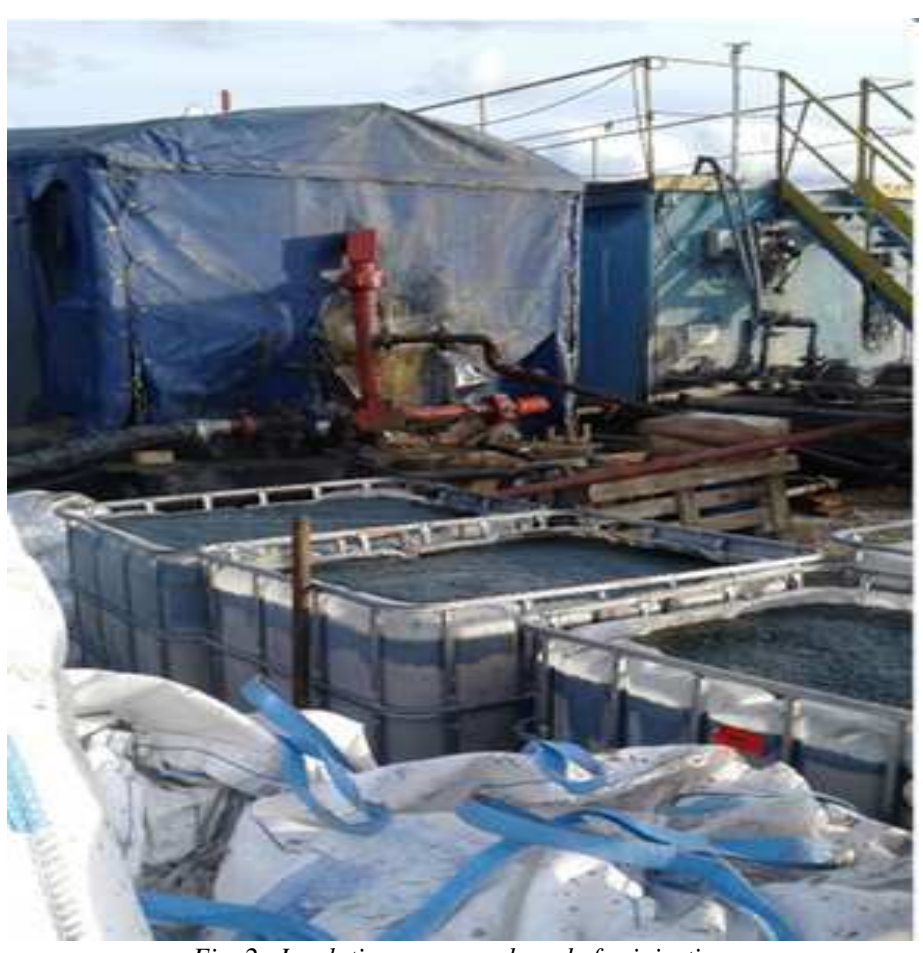

Fig. 2. Insulating compound ready for injection 
An insulating compound close to well conditions after 4 hours of reacting at a temperature of 58 degrees is shown in Fig. 3.
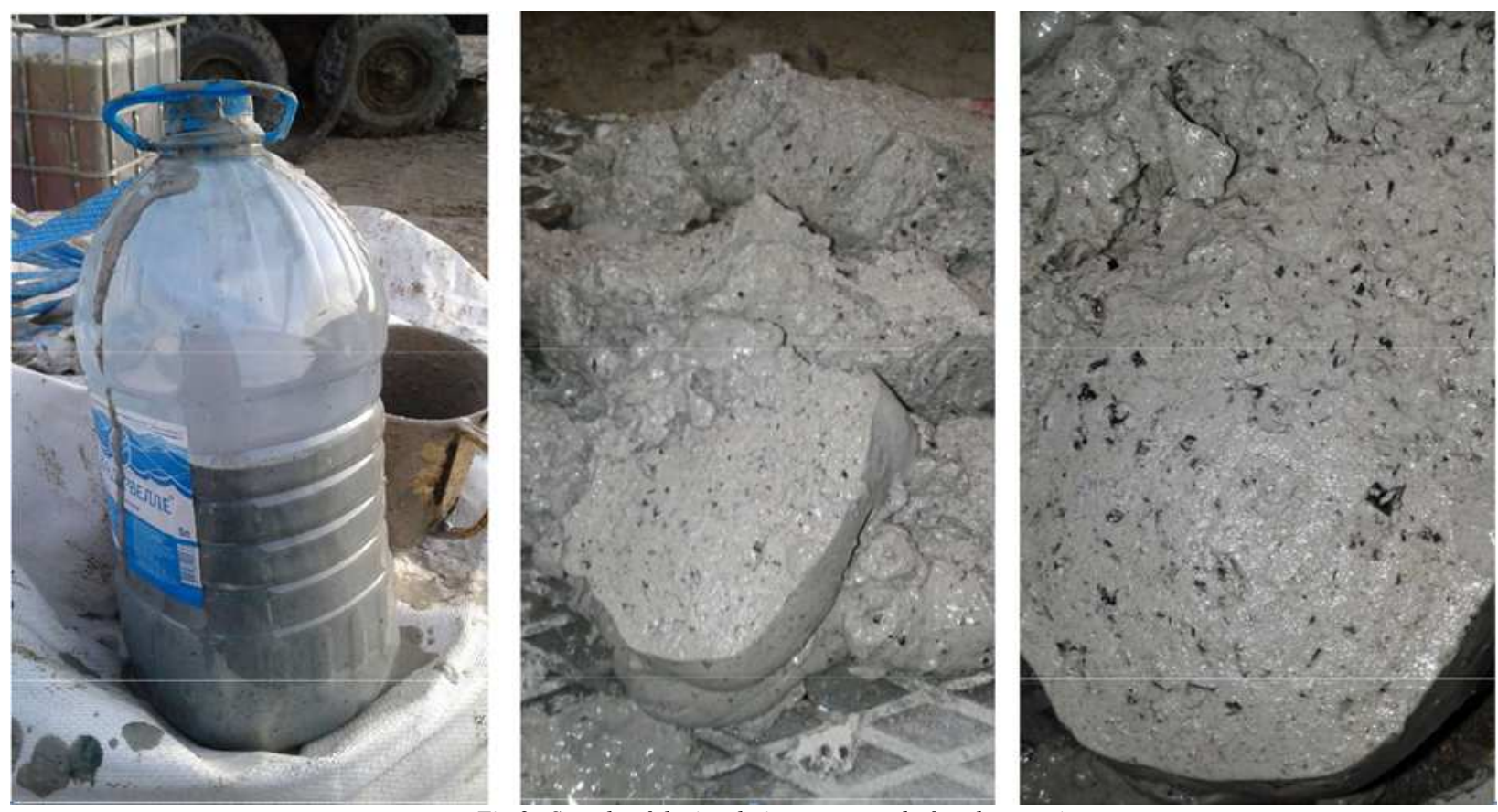

Fig.3. Sample of the insulating compound after the reaction

\section{Results}

1. The composition significantly reduces the time of catastrophically lost circulation curing with no cement plugs.

2. The change in the assembly of drilling string bottom proves to be not necessary

3. The approach does not require drilling out after killing and overlapping of the loss formation.

4. Low cost, easiness in the making, because it does not require the delivery of additional chemical reagents, reduces the time for catastrophic loss to be cured.

5. It is compatible with any type of drilling mud (water-base mud, hydrocarbon-base mud).

\section{The economic analysis of the considered methods}

\section{Cement plug placing costs}

Information on the calculation of the cost of a cement plug is presented in Table 1.

Table 1. A cement plug placing cost estimate

\begin{tabular}{|c|c|c|c|}
\hline Indicators & Number of pieces & Price, thousand rubles & Amount, thousand rubles \\
\hline 1 & 2 & 3 & 4 \\
\hline Cement plug & 1 & 200 & 200 \\
\hline $\begin{array}{c}\text { Engineering support for } \\
\text { drilling }\end{array}$ & 1 & 28 & 28 \\
\hline Total & 2 & 228 & 228 \\
\hline
\end{tabular}

It takes 48 hours to place the cement plug.

Payroll accounting for the drilling shift for cement plug to be placed.

Information on the calculation of wages for a drilling shift during the cement plug placing is presented in Table 2. 
Table 2. Payroll accounting for the drilling shift for cement plug to be placed

\begin{tabular}{|c|c|c|c|c|c|c|}
\hline Position & $\begin{array}{c}\text { Hour. Tariff } \\
\text { (rub.) }\end{array}$ & Bonus \% & $\begin{array}{c}\text { Locality } \\
\text { pay factor }\end{array}$ & $\begin{array}{c}\text { Per hour } \\
\text { (rub.) }\end{array}$ & $\begin{array}{c}\text { For 48 } \\
\text { hours. (rub.) }\end{array}$ & $\begin{array}{c}\text { Unified social } \\
\text { tax 34\% (rub.) }\end{array}$ \\
\hline $\begin{array}{c}\text { Driller of the 6 } \\
\text { category }\end{array}$ & 130 & 10 & 1.2 & 171.6 & 8236.8 & 2800.5 \\
\hline $\begin{array}{c}\text { Driller rotary } \\
\text { helper of the 5 } \\
\text { category }^{\text {th }}\end{array}$ & 100 & 10 & 1.2 & 132 & 6336 & 2154.2 \\
\hline $\begin{array}{c}\text { Driller rotary } \\
\text { helper of the 5 } \\
\text { category }\end{array}$ & 100 & 10 & 1.2 & 132 & 6336 & 2154.2 \\
\hline $\begin{array}{c}\text { Driller rotary } \\
\text { helper of the 4 } \\
\text { category }\end{array}$ & 85 & 10 & 1.2 & 112.2 & 5385.6 & 1831.1 \\
\hline Total & & & & & 26294.4 & 8940 \\
\hline
\end{tabular}

Calculation of grouting technique required.

To place a cement plug, 3 pieces of equipment comprising 1 mixer and 2 Cementing Truck-320 are

Expenses for equipment for 24 hours of operation include:

The cost of each equipment is 800 rubles per hour; therefore, for 24 hours of work, the cost of equipment will be: $800 * 24=19200$ rub.

Determining the cost of all equipment: $19200 * 3=57600$ rub.

All costs for the cement plug to be placed are presented in Table 3.

Table 3. Cement plug placing costs

\begin{tabular}{|l|c|}
\hline \multicolumn{1}{|c|}{ Cost name } & $\begin{array}{c}\text { Units of measurement (thousand } \\
\text { rubles) }\end{array}$ \\
\hline Materials & 200 \\
\hline Wages & 26.3 \\
\hline Unified social tax & 8.9 \\
\hline Equipment & 57.6 \\
\hline Outsourced services & 28 \\
\hline Total & 320.8 \\
\hline
\end{tabular}

The cost of installation an insulating compound based on chromium acetate

Information on the cost of an insulating compound based on chromium acetate is presented in Table 4.

Table 4. .Calculation of the cost of an insulating compound based on chromium acetate

\begin{tabular}{|c|c|c|c|}
\hline Indicators & Number of pieces & Price, thousand rubles & $\begin{array}{c}\text { Amount, thousand } \\
\text { rubles }\end{array}$ \\
\hline 1 & 2 & 3 & 4 \\
\hline $\begin{array}{c}\text { Chromium Acetate } \\
\text { Insulating Compound }\end{array}$ & 1 & 200 & 200 \\
\hline $\begin{array}{l}\text { Engineering support for } \\
\text { drilling }\end{array}$ & 1 & 28 & 28 \\
\hline Total & 2 & 228 & 228 \\
\hline
\end{tabular}

It takes 14 hours to install the chromium acetate-based insulating compound.

Payroll accounting for the drilling shift for the insulating compound to be placed

Information on the calculation of wages for a drilling shift during the insulating compound placing is presented in Table 5. 
Table 5. Calculation of wages for the drilling shift during the installation of the insulating compound based on chromium acetate

\begin{tabular}{|c|c|c|c|c|c|c|}
\hline Position & $\begin{array}{c}\text { Hour. Tariff } \\
\text { (rub.) }\end{array}$ & Bonus \% & $\begin{array}{c}\text { Locality } \\
\text { pay factor }\end{array}$ & $\begin{array}{c}\text { Per hour } \\
\text { (rub.) }\end{array}$ & $\begin{array}{c}\text { For 14 } \\
\text { hours. (rub.) }\end{array}$ & $\begin{array}{c}\text { Unified social } \\
\text { tax 34\% (rub.) }\end{array}$ \\
\hline $\begin{array}{c}\text { Driller of the 6 } \\
\text { category }\end{array}$ & 130 & 10 & 1.2 & 171.6 & 2402.4 & 816.8 \\
\hline $\begin{array}{c}\text { Driller rotary } \\
\text { helper of the 5 } \\
\text { category }\end{array}$ & 100 & 10 & 1.2 & 132 & 1848 & 628.3 \\
\hline $\begin{array}{c}\text { Driller rotary } \\
\text { helper of the 5 } \\
\text { category }\end{array}$ & 100 & 10 & 1.2 & 132 & 1848 & 628.3 \\
\hline $\begin{array}{c}\text { Driller rotary } \\
\text { helper of the } 4^{\text {th }} \\
\text { category }\end{array}$ & 85 & 10 & 1.2 & 112.2 & 1570.8 & 534.1 \\
\hline Total & & & & & 7669.2 & 2607.5 \\
\hline
\end{tabular}

Calculation of grouting technique.

For the injection and squeezing of an insulating compound based on chromium acetate, 1 unit of equipment aka 1 cementing truck - 320 is required. The unit will run for 4 hours.

Expenses for equipment for 4 hours of operation include: The cost of equipment is 800 rubles per hour; therefore, for 4 hours of work, the cost of equipment is: $800 * 4=3200$ rubles.

All costs for the installation of an insulating compound based on chromium acetate are shown in Table 6

Table 6. The cost of installation an insulating compound based on chromium acetate

\begin{tabular}{|l|c|}
\hline \multicolumn{1}{|c|}{ Cost name } & $\begin{array}{c}\text { Units of measurement } \\
\text { (thousand rubles) }\end{array}$ \\
\hline Materials & 200 \\
\hline Wages & 7.7 \\
\hline Unified social tax & 2.6 \\
\hline Equipment & 3.2 \\
\hline Outsourced services & 28 \\
\hline Total & 241.5 \\
\hline
\end{tabular}

QUICK-STONE ${ }^{\mathrm{TM}}$ compound installation costs

Information about the calculation of the cost of the QUICK-STONE compound is presented in Table 7

\begin{tabular}{|c|c|c|c|}
\multicolumn{4}{|c}{ Table 7. Calculation of the cost of the QUICK-STONE } \\
\hline Indicators & Number of pieces & Price, thousand rubles & $\begin{array}{c}\text { Amount, thousand } \\
\text { rubles }\end{array}$ \\
\hline 1 & 2 & 3 & 4 \\
\hline $\begin{array}{c}\text { QUICK-STONE TM } \\
\text { composition }\end{array}$ & 1 & 700 & 700 \\
\hline $\begin{array}{c}\text { Engineering support for } \\
\text { drilling }\end{array}$ & 1 & 28 & 28 \\
\hline Total & 2 & 728 & 728 \\
\hline
\end{tabular}

It takes 18 hours to install QUICK-STONETM.

Calculation of wages for the drilling watch during the installation of the QUICK-STONE TM train.

Information on the calculation of wages for a drilling shift during the placing of an insulating compound based on chromium acetate is presented in Table 8 . 
Table 8. Calculation of wages for the drilling shift during the installation of the QUICK-STONE ${ }^{\mathrm{TM}}$

\begin{tabular}{|c|c|c|c|c|c|c|}
\hline Position & $\begin{array}{l}\text { Hour. Tariff } \\
\text { (rub.) }\end{array}$ & Bonus \% & $\begin{array}{l}\text { Locality } \\
\text { pay factor }\end{array}$ & $\begin{array}{l}\text { Per hour } \\
\text { (rub.) }\end{array}$ & $\begin{array}{c}\text { For } 18 \\
\text { hours. (rub.) }\end{array}$ & $\begin{array}{l}\text { Unified social } \\
\text { tax 34\% (rub.) }\end{array}$ \\
\hline $\begin{array}{l}\text { Driller of the } 6^{\text {th }} \\
\text { category }\end{array}$ & 130 & 10 & 1.2 & 171.6 & 3088.8 & 1050.2 \\
\hline $\begin{array}{l}\text { Driller rotary helper } \\
\text { of the } 5^{\text {th }} \text { category }\end{array}$ & 100 & 10 & 1.2 & 132 & 2376 & 807.8 \\
\hline $\begin{array}{l}\text { Driller rotary helper } \\
\text { of the } 5^{\text {th }} \text { category }\end{array}$ & 100 & 10 & 1.2 & 132 & 2376 & 807.8 \\
\hline $\begin{array}{l}\text { Driller rotary helper } \\
\text { of the } 4^{\text {th }} \text { category }\end{array}$ & 85 & 10 & 1.2 & 112.2 & 2019.6 & 686.6 \\
\hline Total & & & & & 9860.4 & 3352.5 \\
\hline
\end{tabular}

Calculation of grouting technique

For the injection and squeezing of the insulating compound based on chromium acetate, 2 units of equipment, including 1 Cementing Truck-320, 1 Mixing unit - 20R1 are necessary. The equipment will operate for 18 hours.

Determination of the cost of equipment for 18 hours of work:

The cost of equipment is 800 rubles per hour; therefore, for 18 hours of operation, the cost of equipment will be: $800 * 18=14400$ rub.

Determining the cost of all equipment: $14400 * 2=28800$ rub.

All costs for the installation of the QUICK-STONETM compound are shown in Table 9

Table 9. QUICK-STONE ${ }^{\mathrm{TM}}$ compound installation costs

\begin{tabular}{|l|c|}
\hline \multicolumn{1}{|c|}{ Cost name } & $\begin{array}{c}\text { Units of measurement (thousand } \\
\text { rubles) }\end{array}$ \\
\hline Materials & 700 \\
\hline Wages & 9.9 \\
\hline Unified social tax & 3.4 \\
\hline Equipment & 28.8 \\
\hline Outsourced services & 28 \\
\hline Total & 770.1 \\
\hline
\end{tabular}

\section{Conclusion}

\section{Povisit na polovinu stranice bez tablice}

A comparative analysis of the use of QUICK-STONETM, chromium acetate-based insulating compound, and cement plug is presented in Table 4.10.

Analysis of the use of QUICK-STONE TM and chromium acetate sealant and cement plug

\begin{tabular}{|l|c|c|c|}
\hline \multicolumn{1}{|c|}{ Technology } & $\begin{array}{c}\text { Chromium Acetate } \\
\text { Insulating Compound }\end{array}$ & $\begin{array}{c}\text { QUICK-STONE TM } \\
\text { composition }\end{array}$ & Cement plug \\
\hline Cost name & \multicolumn{2}{|c|}{ Units of measurement (thousand rubles) } \\
\hline Materials & 200 & 700 & 200 \\
\hline Wages & 7.7 & 9.9 & 26.3 \\
\hline Unified social tax & 2.6 & 3.4 & 8.9 \\
\hline Equipment & 3.2 & 28.8 & 57.6 \\
\hline Outsourced services & 28 & 28 & 28 \\
\hline Total & 241.5 & 770.1 & 320.8 \\
\hline
\end{tabular}

Based on the data in Table 4.10, it can be concluded that from the economic point of view, the use of an insulating compound based on chromium acetate is 3.2 times more profitable than using the QUICK-STONE TM compound, as well as 1.4 times more than installing a cement bridge. 
The use of an insulating composition based on chromium acetate, in contrast to the technologies discussed above, enables oil producers:

1) to reduce significantly the time to cure a catastrophic loss, with no cement plugs;

2) to eliminate the need to change the assembly of drilling string bottom;

3) to escape drilling out after shutdown of the thief formation;

4) to develop compound instantly because it does not require the delivery of additional chemical reagents and special equipment, which also reduces the time for catastrophic loss to be cured;

5) to use with any type of drilling mud (water-based mud, hydrocarbon-based mud).

\section{References}

Akatov, N., Klačková, I., Mingaleva, Z., Galieva, G. and Shaidurova, N. (2019). Expert technology for risk management in the implementation of QRM in a high-tech industrial enterprise. Management Systems in Production Engineering 2019, Volume 27, Issue 4, pp. 250-254.

American Petroleum Institute. (2010). Isolating Potential Flow Zones During Well Construction. Washington D.C., USA: American Petroleum Institute, API RP 65 Part 2.

Arjmand, Y., Latifi, B. and Dehvedar, M. (2017). An overview on mud filtration in oil wells and its relations. In: Materials of 4th international conference on recent innovations in chemistry \& chemical engineering, Iran, Tehran. April 2017.

Basarygin, Yu. M., Bulatov, A.I. and Proselkov Yu.M. (2000). Complications and accidents while drilling oil and gas wells. Textbook. for universities. - M.: LLC Nedra-Business Center, 679 p.

Basarygin, Yu. M., Bulatov, A.I. and Proselkov Yu.M. (2001). Oil and gas well drilling technology. Textbook for universities. - M.: LLC Nedra-Business Center, - 679 p.

Bauer, M. and Tóth, T. M. (2017). Characterization and DFN modeling of the fracture network in a Mesozoic karst reservoir: Gomba oilfield, paleogene basin, Central Hungary. Journal of Petroleum Geology, Vol. 40(3), July 2017, pp $319-334$.

Bulatov, A. I., Makarenko, P. P. and Proselkov, Yu. M. (1999). Drilling washing and cementing slurries: Textbook for universities. - M.: JSC Nedra Publishing House, 424 p.

Dodok, T., Čuboňová, N., Císar, M., Kuric, I. and Zajačko, I. (2017). Utilization of strategies to generate and optimize machining se-quences in CAD/CAM. In Book Series Procedia Engineering 2017, Volume 192, pp. 113-118.

Elbakian, A., Sentyakov, B., Bozek, P., Kuric, I. and Sentyakov, K. (2018). Automated separation of basalt fiber and other earth resources by the means of acoustic vibrations. In Acta Montanistica Slovaca. Vol. 23, no. 3, pp. 271-281.

Eremin, A., Eremin, N. and Eremin, N. A. (2013). Smart Fields and Wells: Textbook for universities. - Almaty: Kazach-British technical Univrsity, 2013. - 429 p.

Figiel, A. and Klačková, I. (2020). Safety requirements for mining complexes controlled in automatic mode. In Journal Acta Montanistica Slovaca 2020, Volume 25, 3; ISSN 1335-1788, DOI 10.46544/AMS.v25i3.13.

Gaurina-Medimurec, N., Pašic, P., Mijjic, P. and Medved, I. (2021). Drilling Fluid and Cement Slurry Design for NaturallyFractured Reservoirs. Appl. Sci. 2021, 11, 767. https://doi.org/10.3390/app11020767.

Ivanova T.N., Żabińska I. (2021). Modern Methods of Elimination of Lost Circulation in Directional Wells. Management Systems in Production Engineering. Volume 29, issue 1. pp. 65-74. DOI: 10.2478/mspe2021-0009.

Kuric, I., Cisar, M. and Tlach, V. (2019). Technical Diagnostics at the Department of Automation and Production Systems. Advances in Intelligent Systems and Computing 2019, pp. 474-484.

Lawrence, O. A. (2009). Geologic assessment of undiscovered oil and gas in the Powder River Basin Province: U.S. Geological Survey Digital Data Series DDS-69-U, 93 p.

Maláková, S., Frankovský, P., Harachová, D. and Neumann, V. (2019). Design of constructional optimization determined for mixer truck gearbox. Ad Alta: Journal of Interdisciplinary Research, 9(2).

Pástor, M., Živčák, J., Púškár, M., Lengvarský, P. and Klačková, I. (2020). Application of Advanced Measuring Methods for Identifica-tion of Stresses and Deformations of Automotive Structures. In Journal; Applied Sciences - Basel 2020, Volume 10, Issue 21, arti-cle number 7510, MDPI, ISSN 2076-3417.

Repko, A., Saga, M., Sentyakov, B. and Sviatskii, V. (2020). Development and Testing of a Block Hydrocyclone, Processes, Vol.:8, Issue: 12, Article Number: 1577, DOI: 10.3390/pr8121577

Sentyakov, K., Peterka, J., Smirnov, V., Bozek, P. and Sviatskii, V. (2020). Modeling of Boring Mandrel Working Process with Vibration Damper. In Materials. Vol. 13, iss. 8 (2020), pp.1-13. DOI: 10.3390/ma13081931

Vasko M., Saga M., Majko J., Vasko A. and Handrik M. (2020). Impact Toughness of FRTP Composites Produced by 3D Printing, Materials, Vol.13, Issue 24, Article No: 5654, DOI: 10.3390/ma13245654 